\title{
Scribe's Column
}

\section{'I'm dreaming of a Bryon Gysin Christmas'}

The philosopher, William James, had a vivid dream following the inhalation of nitrous oxide. When he woke he had a clear memory of an eternal truth but rapidly forgot it. The next night the dream recurred when he had a pad by his bed, and he found he had written:

Higgamous Hoggamous, woman is monogamous: Hoggamous Higgamous, but man is polygamous.

I believe he was disappointed when he discovered this eternal verity, though it seems as valid a truth as any. Coleridge had a similar problem with opium and if it hadn't been for that wretched person from Porlock we might have a different view of Xanadu, if not of Rosebud. I had a similar experience after three months on a diet of Fish (Frank Fish). Those who fast regularly know that on certain holy days one is absolved from the most severe rigours, so over the Christmas Holiday I voraciously read a number of other texts dealing with Alternative Therapies. Following this $\mathrm{Christmas}$ reading I fell into a troubled sleep and had a dream so vivid that on waking I wrote an account of it immediately, and later found that I too had taken to verse. Whether it is in the style of William James or Coleridge or William McGonagall I will leave to better judges of poesy than myself. Apart from the horror of the doggerel, my unconscious mind seemed overfull of filthy psychopathology, so my New Year's resolution has been to fumigate it by re-reading the entire works of Aubrey Lewis. Next year this should be a decently sanitized column again.

\section{Ezra's Dream}

Come holy Freud and with your spell

Unlock my mind and make me well.

Things are not always what they seem,

Upon the couch I had a dream

Of quacks and psychiatric sinners,

As many as I've had hot dinners,

Crossing the analytic plane,

Selling their views with might and main.

I saw this from a padded womb,

Good Oedipus can I assume

The Id was out and on the route

The Superego made pursuit?

Into the market came the schools Selling their bogus wares to fools.

Dolts and dunces led the way

To show which had the loudest bray.

A Californian column came

So Eric Berne could play his game

With zanies, crackpots and much odder

And money for transaction fodder.
As Mary Baker Eddy said

You are not ill (unless you're dead)

And though she has herself succumbed

Her doctrine lives. The soul is numbed

When Szasz arrives to shake his fists

At those who think the mind exists,

And can be prey to illness too.

For Thomas Szasz this will not do,

A myth is how it's re-defined

'There is no illness of the mind'.

The Jews did not exist for Fascism

Nor the insane for Thomas Szaszism.

And here is Laing who'll be remembered For having English prose dismembered. Psychiatrists think him a poet.

Writers a shrink. The latter know it, Having his books to prove their point; They show his verse is out of joint With knots and Jack and Jill to write on In style derived from Enid Blyton, And prose that's full of empty sound So platitudes appear profound (Another who in slogans thinks And from the fount of T. Szasz drinks).

Then Esterson comes to the fore The Existential Marxist bore.

And then to chant that sex was super Came co-disciple David Cooper.

Arthur Janov is another

Who thinks that we should look to mother.

When upside down we first appear

And feel the shock that causes fear. He does not analyse a dream,

But quarries out the primal scream.

He says, encourage them to shout And let the ghastly matter out.

(Though some who fail to get the art May reproduce the primal fart.)

Please do not think that this is funny,

These schools of treatment need the money.

Ron Hubbard and his Scientology Impose themselves without apology (They're Citizens Commission now For Human Rights they take a bow). And if they do not like my verse They'll take me to the Courts or worse. 
102

The Orgone's here, the Orgone's there Reich has found it everywhere. In death at least he is much calmer Wrapped in his last motoric armour.

Libido here, libido there, The healers sought it everywhere. The Guru movement ran along With wine and sin and sex and song And left a million miles behind Old fashioned healers of the mind. (A dull and dreary group who ply, With sceptic minds and squares of chi, Who randomize their boring trials Of Guru versus Roche's phials,

And end the day by bluntly stating 'Neither works on any rating'. 'Placebo lives' or so they say 'To cure us all another day'.)

As Sargant said, at side of bed, 'This is the place to cure the head'. (Celestial beds were all the rage When Mrs Siddons trod the stage. Come back Graham, all's forgotten, There's room for quacks, both good and rotten.) 'They all are cured by pill and potion',
BULLETIN OF THE ROYAL COLLEGE OF PSYCHIATRISTS, VOL 9, MAY 1985

Was once the true St Thomas' notion.

Another trial threw a spanner Into the works of bedside manner. And now one can no longer say 'I cured them by the bed today'.

The only thing we state at last Is ECT is safe and fast And penicillin cures the pox, Before the therapist unlocks

The traumas, complexes and binds That fill the sad unconscious minds Of those who suffer from the strain Of spirochaetes within the brain.

And here the pen jumped from my hand, No longer heeding my command, And started writing down: 'It's Stuff And Nonsense. That's enough I will not write another word,

You're sound asleep, your dream's absurd.

You seem to me a foolish berk,"

It's time you woke and got to work.'

* Believed to be Joseph Berke.

\section{Society of Psychiatrists of South Africa (MASA): Position Statement}

Council discussed this statement at its meeting on 20 March 1985. It was warmly received and the President was asked to write to the President of the Society of Psychiatrists of South Africa conveying Council's agreement with the views expressed in this statement.

On 31 January 1985 the Society of Psychiatrists declared that:

1. The Society of Psychiatrists recognizes and deplores potentially harmful psychological effects on the people of South Africa as a result of any form of discrimination based on race, colour, gender or creed. The Society does and will strive for the elimination of all forms of discrimination that adversely affect mental health.

2. The Society declares its opposition to any disparities in the quality of psychiatric services for all.

3. The Society declares its commitment to insist its members practise their profession as laid out in internationally accepted ethical codes in the Declaration of Helsinki, Hawaii and Tokyo and its determination to resist any form of abuse of psychiatric knowledge and skills for political ends or for any other purpose contrary to the best interests of the patients and their personal welfare.

4. The Society has by its representation and actions been responsible for many improvements in the services for all psychiatric patients in South Africa. The Society steadfastly declares its intention to continue these efforts.

President

Society of Psychiatrists of South Africa

\section{'Guidelines for Regional Advisers on Consultant Posts in Psychotherapy'}

The document prepared by the Psychotherapy Specialist Section, entitled 'Guidelines for Regional Advisers on Consultant Posts in Psychotherapy' (Bulletin, February 1985, 9, 40-1), was formally approved by the Court of Electors at its meeting in June 1984.
Professor Henry Walton has been awarded the Jofre Medal by the Spanish Society for Advancement of Psychiatry. 